\title{
Testing Trade-off, Agency Cost and Pecking Order Predictions of Capital Structure: Lessons from the Pakistani Experience
}

\begin{abstract}
Dr. Fazal Husain ${ }^{1}$
Dr. Sajid Gul ${ }^{2}$

ABSTRACT

Why the financial structure is still believed to be relevant within business firms? A number of competing theories have been developed for explaining this question. The three theories that stand out are Pecking order, Trade off and Agency cost. However, the first two are frequently referred to and contradictory to each other. The 'trade-off' theory suggests that corporate taxes in combination with bankruptcy costs imply that there exists an optimal combination of debt and equity capital that management should search for in order to maximize shareholder value. The challenging 'pecking order' theory recognizes no such optimum, but instead states that there is a ranking order in the firms between different types of capital where the issuance of equity capital is seen only as a last resort. This paper examines the role and importance of different firm characteristics that explain financial structure as well as the theories that best fit in Pakistani context and considers concepts like optimal capital structure, risk, financial hierarchy and asymmetric information. The sample of the study consists of firms extracted from financial (70 firms) and non-financial (120 firms) sectors listed on the KSE for a period of 2000-2013. Secondary data is extracted from firm's annual reports. The sources like SBP publications; Bloom burgee business week and KSE were used to collect data. The results indicate that firms in the two sectors prefer funds generated internally for financing their assets. Moreover debt will be preferred to equity once external funds are required. The pecking order appears to be a good description of financing behavior for a large sample of firms over a long time period after accounting for debt capacity. We have also studied agency theory of the firm however there was little evidence to support the Agency cost theory.
\end{abstract}

Keywords: Corporate Finance, Capital Structure, Listed Companies, Unlisted Companies.

\section{INTRODUCTION}

What is the rationale behind financing structure decisions in business firms in practice? Theories targeting these decisions have in common that they depart from more or less reasonable-albeit divergent-assumptions about market efficiency in terms of the objectives, expectations and information accessibility of different stakeholders like shareholders, creditors and managers. In that respect these theories can alone provide only a partial analysis for understanding why a firm is displaying a certain financial structure. Capital structure is basically a mix of company's leverage and equity that a firm uses to finance its assets. By issuing bonds or long-term notes payable firms can generate debt, while equity consists of common stock and preferred stock. In capital structure the percentage of debt is measured by leverages. The capital structure decision is a very important decision in corporate finance field, and is at the center of some other decisions like dividend policy decision, project financing and financing of mergers, buyouts etc. In firm's growth and establishment this has played a very crucial role for many years if we look at the literature of corporate finance. Capital structure decisions provide opportunities' that helps in increasing the wealth of the shareholders. But Opler, Saron and Titman (1997) argues that there exist some difficulties in identifying optimal capital structure that will maximize shareholder value, so due to the difficulties these opportunities' are often passed over without giving due attention.

\footnotetext{
1- Dr. Fazal Husain is Chief of Research and Head of the Economics Department at Pakistan Institute of Development Economics Islamabad, fazalhusain@ @ide.org.pk 2- Dr. Sajid Gul is Assistant Professor at Lahore University of Management Sciences, sajidgul.au@hotmail.com JISR-MSSE 
The trade-off between risk and return is also involved in capital structure policy, because a firm that is using more debt will raises the risks in the firm's earnings stream, which will decrease the value of their stock price. However in contrast companies can achieve higher return by using higher debt level, due to this higher expected rate of return the stock becomes more attractive to investors which in turn, ultimately increase its price. However it is still debatable that what should be an appropriate and acceptable level of financial leverage. The research done on capital structure both theoretically and empirically suggests that there is an optimal capital structure. But in spite of that there are no clear cut guide lines to guide managers to achieve optimal capital structure. Every firm has different capital structure when they try to maximize the overall value. Therefore to explain the variation in the firm's capital structure over time or across regions research has been done on different theories of capital structure. The aim of this study is to analyze the main determinants of the financing behavior of financial and non-financial companies of Pakistan, listed in the "Karachi Stock Exchange". Furthermore, we will try to analyze which capital structure theory best explains the financial behavior of Pakistani listed firms in the two sectors during the period of fourteen years.

\section{LITERATURE REVIEW}

\section{Theoretical Literature}

The work done so far on firm's capital structure is based on earlier work of Modigliani \& Miller (1958). Modigliani \& Miller claim that the capital structure and value of the firms do not relate to each other, in fact the assets profitability is responsible for fluctuations in firm value and do not depend on the way of financing these assets. The MM proposition is based on perfect capital market assumptions in which the cost of bankruptcy, transaction cost, information asymmetry and taxes are absent. The theory of pecking order, the theory of agency cost and trade-off theory are the most important theories of capital structure and are based on examining what happens if the assumptions of M\&M do not hold. Therefore, the purpose of this part of the research is to highlight the capital structure theories and explanations. We will try to shed some light on Pecking order, Trade-off and agency cost theory to find whether they are relevant in the context of Pakistan. The chapter is structured as follows: the theoretical literature on pecking order, trade-off and agency cost theories of capital structure is presented.

\section{Pecking Order Theory (POT)}

Myers and Majluf (1984) first introduced the pecking order framework. According to this theory firms first use internal equity as compare to debt, and if required they will use external equity (Myers, 1984). This theory is against the proposition of Modigliani \& Miller, which states that there are no information asymmetries and investors and managers both have the same information. POT says that due to the cost of information asymmetry managers will first use such sources for financing projects that have low agency cost. According to Myer and Majluf (1984) this hierarchy in financing projects is based on certain hypothetical foundations; (i) the reason for giving first priority to their internal funds (retained earnings) for financing new investments is that "firm has no well-defined D/E ratio". (ii) Firms equity will be miss-priced because of information asymmetry in the market place due to which, "market value of firm's existing shares decreases. This is due to the adverse selection problem that arises because managers have better knowledge than outside investors. 
Hence for making the inefficiencies less severe caused by asymmetric information in the investment decision of the firm, Myers and Majluf (1984) suggest that firms need to borrow through the use of debt instrument that are less risky. The reason is that debt contracts are safer in that they limit the possible ways by which holders could lose, therefore debt has low adverse selection problem as compare to equity. If the firm is overvalued only then the managers will issue equity, and when it is undervalued then they will go for debt Myer and Majluf (1984). Further, they claim that when financial distress risk becomes high, external equity is issued otherwise; hybrid securities and straight debt at moderate risk are issued. Myers (2001) supports this argument and says that due to expensive debt, firms will issue external equity, for example when firm's debt ratio is very high so that the cost of financial distress is expected by managers and investors of the firm. Moreover, according to Myers (2001) investors will reject the issue of equity when debt is available on reasonable terms, and also debt will be issued in a situation of equilibrium? Therefore, Myers argues that equity is the residual claim, while debt has the prior claim on assets and earnings.

\section{Trade-Off Theory (TOT)}

The Trade-Off Theory of Capital Structure refers to the idea that how much debt finance and how much equity finance a company must choose by balancing the costs and benefits of debt. According to this theory there is an advantage of financing with debt, the tax benefits of debt and there is a cost of financing with debt, the costs of financial distress including bankruptcy costs of debt and non-bankruptcy costs. Modigliani and Miller (1963), in their second seminal paper have altered the underlying argument of their classical proposition of capital structure. Modigliani \& Miler incorporate the corporate income tax and contend that the firm value, if levered, equals to the value of the firm if unlevered plus the value of the generated tax benefit. They still ignore the bankruptcy costs of debt, however to certain limits; its presence may outweigh its tax benefit, suggesting that there is some threshold level of debt, under which the firm's value is maximized. This threshold of debt is defined by the trade-off between costs and benefits of debt and is generally called the optimal (target) level of capital structure. More precisely, this target level of capital structure will be achieved at a point where the marginal benefits of each additional unit of debt equal to its marginal costs.

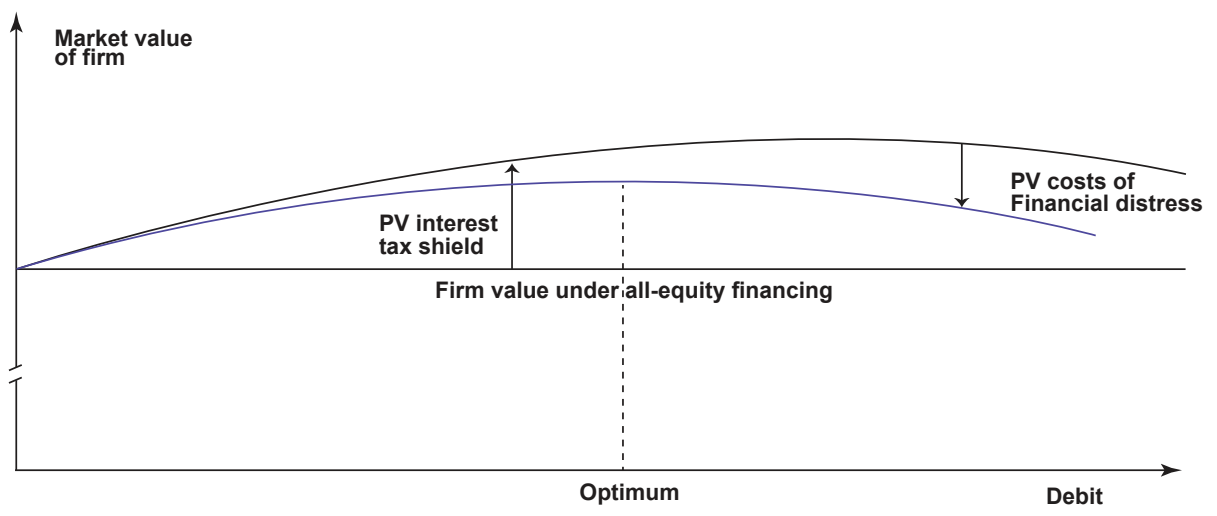

Figure 1: Myers (1984) trade-off theory of capital structure

It can be seen in figure 1 that with the increase of debt, the present value of tax shield also increases initially and the present value of financial distress is insignificant at that point. However with over exceeded debt the present value of financial distress increases while the present value of tax shield starts decreasing at a certain point. 


\section{Agency Cost Theory (ACT)}

The management of a firm influences the capital structure choice. Myers (2001) states that instead of increasing the wealth of shareholders managers might work for their personal incentives. Jensen and Meckling (1976) were the first who initiated research in this field. They identified that possible interest conflicts are of two types: the first one is between management and shareholder, and the second one is between shareholders and debt holders. The problem of agency cost according to Gillan and Starts (2003) arises not only because of the separation between ownership and control, but it can also arise due to the diffuse nature of corporate ownership, because small shareholders cannot monitor the behavior of management due to high costs. The manager-shareholder conflict and the cost arising from this conflict will increases when free cash is available to managers. Stulz (1990) modeled the Jensen (1986) theory of free cash flow in which the agency problem was addressed. Free cash flow is defined by Jensen (1986) as "Free cash flow refers to cash flow available after funding all projects with positive cash flows".

The agency cost of shareholder-manager conflict decreases with the introduction of debt, but the agency cost of shareholder and debt holder will arise with over exceeded debt. Debt as mentioned above, when increases aggravates the shareholder and debt holder conflict, because shareholder has an incentive provided by the debt contract to invest sub optimally. Shareholder can overinvest the debt funds in projects that are risky to extract value from shareholders (Jensen \& Meckling, 1976). This behavior of Shareholders' creates the problem of overinvestment. Shareholders profit from the likelihood of larger gains at the expense of larger potential losses. As a result the value of the firm goes down and wealth is transferred from creditors to owners. Thus creditors will demand a premium for compensation, as a result the cost of debt will increase, this cost will be more troublesome for firms facing financial distress it is also called the agency cost of asset substitution. In a different scenario, if debt holders receive most of the return, then even if the project has positive NPV it may be rejected by the shareholders due to which the underinvestment problem arises.

\section{Empirical Literature}

Fan et al (1997) while studying the financing decision of company's management in Hong Kong during the Asian crises found that companies that are facing a period of distress will use equity as a first choice for financing projects. The argument of pecking order theory was opposed by Ihamuotila (2004), who states that firms will use external equity for financing their investment opportunities as compare to debt if old and large shareholders have more knowledge about firm value than others. Tamulyte (2012) shows that Liquidity was an important determinant in all Baltic States, especially in Short term leverage and Trade Credit/Total Assets models. Profitability is an important determinant in Lithuanian and Russian companies, signalling about the existent Pecking Order Theory. Sayeed (2007) during the period of 2001-2005 finds that pecking order theory is applicable to financial behavior of firms in energy sector of Pakistan. Afza and Hussain (2011) studied the impact of size, profitability, tangibility of assets, and cost of debt, taxes, liquidity and non-debt tax shield on leverage for a sample of 37 firms. They found that firms in their sample with good liquidity position and large depreciation allowances use retained earnings, followed by debt financing for growth and smooth operations and equity financing is considered as a last resort. Their results supported the Static Tradeoff Theory and Pecking Order Theory. Ilyas (2008) find that pecking order theory is applicable to financing behavior of firms in Pakistani listed non-financial firms. They show that in Pakistan firms mostly use their internal equity for financing projects as compare to debt or external equity. Using debt ratio as the dependent 
variable, and profitability, non-debt tax shield, tangibility, growth opportunity and liquidity as the explanatory variables Wahab et al, (2012) for the period of 2001-2010 has shown that only profitability and tangibility are significant in explaining variation in leverage while non-debt tax shield, growth opportunity and liquidity are insignificant in explaining variation in leverage.

Fitim-Deari and Media-Deari (2009) in their investigation into Macedonian listed and unlisted companies find support for pecking order theory during the period 2005-2007. For a sample of over 19,000 Brazilian firms and 13 years of data Forte, Barros and Nakamura (2013) finds that profitability is negatively related to leverage, and growth is positively related to leverage. Both results are consistent with the pecking order theory of capital structure. Akinyomi and Olagunju (2013) investigated that in Nigerian manufacturing firms leverage has a negative relationship with firm size and tax on one hand and a positive relationship with tangibility of assets, profitability and growth on the other hand. However, only with tangibility of assets and firm size that significant relationship is established. Çekrezi, (2013) for a sample of 65 Albanian firms, over the period 2008-2011 found that tangibility, liquidity, profitability and size have a significant impact on leverage. Also empirical evidence reveals a significant negative relation of profitability to leverage and a significant positive relation of Size to leverage.

In a comparative study Rajan \& Zingales (1995) do not find support for trade-off theory in US companies. They use profitability, size, tangibility and growth variables as firm specific factors, and report that firms with large amount of collateral assets do not use higher debt level which is against the prediction of TOT while profitability and growth are negatively related to debt ratio supporting the prediction of POT. Moreover they do not find any relation of size variable with debt ratio, and hence contradicts TOT. The findings of the study by Aremu et al (2013) revealed that the main determinant factors which contribute to the bank leverage level of the Banking industry in Nigeria between the years 2006 to 2010 are mainly bank size, dividend payout, profitability, tangible assets, growth, business risk and tax charge factors with all of these factors conforming to sign expectations based on theoretical findings. Bulent, Cuneyt and Arif (2013) found that tax-related factors and asset tangibility are the most economically significant factors for short-term and long-term debt ratios, respectively. Overall, the trade-off theory appears to be more successful than the pecking order theory in accounting for the capital structure of Turkish non-financial firms.

For a sample of 33 firms in the sugar sector during the period 1999-2004 Awan et al, (2011) finds that tangibility and profitability variables were highly significant in their study. Shah and Hijazi (2004) finds support for trade-off theory and agency cost theory in their study on Pakistani listed non-financial firms during the period 1997 to 2001 in terms of tangibility, size and growth variable. Delcoure (2007) did not found enough evidence for POT, TOT and agency cost theory and argue that these theories partially explain the capital structure puzzle. Fitim-Deari and Media-Deari (2009) in their investigation into Macedonian companies find little support for trade-off theory during the period 2005-2007. They conclude that pecking order theory is applicable to the financing behavior of their sample firms whereas, some of their results were also consistent with the prediction of trade-off theory. Furthermore, they argue that in Macedonia financial market is poor and bondholders are absent therefore for borrowing money they do not go for issuing bonds and for financing their investment opportunities they prefer retained earnings as compare to external funds. 


\section{RESEARCH METHODOLOGY AND EMPIRICAL DATA}

The research method used in the study was based on the analysis of secondary data obtained from company's financial statements, Karachi Stock Exchange and Bloom Burge Business week. The research analysis was confined to firms in the financial and non-financial sectors that were listed on the "Karachi Stock Exchange".

\section{Sample Selection}

A sample is a subset from a larger population, sampling involve any procedure that uses a portion of a population to infer conclusion about the population Zikmund (2003). We have selected companies from financial and non-financial sectors listed on Karachi Stock Exchange for a period of fourteen years from 2000-2013. Firms that were delisted from KSE during the period from 2000 to 2013 were excluded. Also we excluded all those firms for which data was unavailable on the variables of the study. At the end of this elimination process, 70 financial and 120 non-financial companies were left in the sample for further analysis. Secondary data is extracted from firm's annual reports. Sources like SBP publications; Bloom burgee business week and KSE were used to collect data.

\section{Reliability}

Data is taken from reliable sources to ensure the reliability of the study. Moreover, we have taken the explanatory variables and the regression model from studies that are eminent in this field of capital structure. The results that we found in our study are compared with the results of some previous studies; we have used the related work on firm's characteristics that affect capital structure just to prove the validity of the study.

\section{DATA ANALYSIS}

The theory as outlined in the literature review was used to guide the analysis of the data, with debt ratio as the dependent variable and size, growth, profitability, tangibility, liquidity and NDTS as the explanatory variables. Statistical analysis techniques were used to provide descriptive statistics to determine the mean, median, standard deviation of each construct variable. Correlation matrix is used to check multicollinearity amongst explanatory variables. Panel regression analysis was used to determine the relationship between firm specific factors and dependent variable debt ratio.

\section{The Regression Model}

By applying Panel least square regression model, we are trying to examine different firm characteristics that determine firm's level debt. In Panel regression the slopes and intercepts are treated as constant, it is also called the constant coefficients model. This regression model ignores time space or individual effects. The observations of each firm are stacked on one another. The model assumes that with regard to capital structure all firms are similar and there is no significant industry or time effect on debt ratio. The equation general form is given as:

$\mathrm{DR} i t=\alpha+\sum_{\mathrm{i}}^{\mathrm{n}} \beta \mathrm{i} \mathrm{X} \varepsilon$ it

DR $i t=$ the debt ratio of a company $i$ at period $t$

$\alpha=$ it is the model intercept

$\beta i=$ the change co-efficient for Xit variables

$\mathrm{X} i t=$ the number of explanatory variables of a company $\mathrm{i}$ at period $\mathrm{t}$

$\mathrm{i}=\mathrm{it}$ represent total number of companies i.e. $\mathrm{i}=1,2,3 \ldots \mathrm{N}$ (in this study $\mathrm{N}=46$ companies)

$\mathrm{t}=$ the period of the study i.e. $\mathrm{t}=1,2,3 \ldots \mathrm{T}$ (in our case $\mathrm{T}=8$ years). 
After converting the general form of model into different explanatory variables used in the study the model becomes:

DR $i t=\alpha+\beta_{1}$ SIZE $i t+\beta_{2}$ GROWTH $i t+\beta_{3}$ NDTS $i t+\beta_{4}$ LIQUIDITY it $+\beta_{5}$ TANGIBILITY $i t+\beta_{6}$ PROFITABILITY it $+\varepsilon$ it.

Where:

DR it $=$ the debt ratio for the company $\mathrm{i}$ at period $\mathrm{t}$,

SIZE $i t=$ Represent size of the company $\mathrm{i}$ at period $\mathrm{t}$,

LIQUIDITY $i t=$ Represent current ratio of company $i$ at period $t$,

PROFITABILITY it $=$ NI before taxes/ total assets

NDTS it $=$ Non-debt tax shield of the company $\mathrm{i}$ at period $\mathrm{t}$,

GROWTH it = Annual percentage increase in total assets for company $\mathrm{i}$ at period $\mathrm{t}$,

$\varepsilon$ it $=$ the disturbance term

\section{Measurement of Variables}

Dependent Variable

\section{Debt Ratio}

We use dependent variable of debt ratio (DR it) in our study. In Pakistan according to Shah and Hijazi (2004) majority of firms are small in size therefore access to capital market is difficult for them, because small firms have cost and technical difficulties therefore there total debt consist of higher percentage of short term debt so we use the proxy of total debt divided by total assets to measure capital structure.

Debt ratio $(\mathrm{DR} i t)=$ total debt/total assets

Total debt consists of long term as well as short term financing, while total assets is a combination of current and fixed assets.

\section{Independent Variables}

We have used six independent variables size, growth, liquidity, profitability, non-debt tax shield and tangibility in the study.

\section{Size}

In the area of capital structure the size (SZ it), variable is widely accepted by researchers. There are mix results between the relationship of size and debt ratio. According to trade-off theory the relation of size with debt ratio is positive. Titman and Wessels (1988) argues that large companies will use more debt in their capital structure as compare to smaller firms because of low chances of bankruptcy due to diversification. Therefore lenders prefer larger firms to give loans as compare to smaller firms. On the other hand pecking order theory suggests negative association between size and dependent variable. The reason behind the negative relation according to Rajan and Zingales (1995) is that large firms have less asymmetrical information; therefore their equity issue will not be undervalued by the market. Due to this reason large firms will use less debt compare to equity. Similarly agency cost theory predicts positive association between size and debt ratio. According to Um (2001) firm size may proxy for the debt agency costs (monitoring cost) which arise from the conflict between managers and investors. Um further emphasizes that for larger firms this monitoring cost is lower as compare to firms that are smaller in size, thus due to this reason smaller firms will use less debt where as more debt will be used by larger firms. We take the proxy of total assets to measure the Size variable. 


\section{Liquidity}

We measured liquidity (LQ it) by dividing current assets by current liabilities which is equal to current ratio. The current ratio is used to find the liquidity of a company and its abilities to cover its short term obligations. According to pecking order theory we expect that debt ratio is negatively correlated with liquidity of the firm. Pecking order theory focus on internal funds to finance investment projects than external funds. High liquidity firms can generate sufficient cash inflows and therefore the excess cash inflows can be used to finance investment and operating activities. On the contrary the association of debt ratio with liquidity is positive as far as trade-off theory is concerned; the reason is that high liquidity firms can pay their short term liabilities on time.

\section{Non-debt Tax Shield (Depreciation)}

The trade-off theory of capital structure states that debt provides companies the tax benefits of interest payment. Therefore, according to Modigliani and Miller (1963) companies that are paying higher taxes will maintain higher debt ratio, because it will reduce their tax bill and increase their after tax cash flow. However, firms cannot take full advantage of using debt for tax reasons when they have other tax shields for example investment tax credit deductions or depreciation. The reason according to Ozkan (2001) is that, these deductions are independent of the way a firm chooses to finance its investments, whether it uses debt or not. Thus companies will be less dependent on debt when they have higher non debt tax shields because it substitutes for the tax benefits. They further say that leverage becomes more expensive with the existence of other tax shields because with increasing NDTS the marginal tax savings from an additional unit of debt decreases. The reason is that the chances of bankruptcy increases with increasing debt level, due to which the marginal benefit decreases. We have used depreciation expense which has been taken from companies annual reports and divide it by total assets to measure non debt tax shield.

\section{Growth Opportunities}

According to POT growing companies will use more debt in their capital structure, because their internal funds may not be enough to meet their requirements, they will need more funds for financing their projects and to spend on research and development therefore for meeting their requirements they will go for external finance and will use debt over equity because of minor adverse selection problem. According to Um (2001) growing firms will prefer debt over equity because debt has lower information cost.

We can classify the assets of any company in to two classes, tangible or intangible assets. Trade-off theory and Agency cost theory predicts that the impact of growth variable on debt ratio is negative. The reason for this association according to trade-off theory is that growth opportunities are not collateralizable because they are intangible assets and therefore firms with large amount of intangible assets will find difficulty in obtaining long term debt Titman \& Wessels (1988) and Rajan \& Zingales (1995). In contrast short term debt will have positive association with debt ratio. Moreover, according to agency cost theory growing firms are more flexible with regard to future investments therefore they have higher agency cost, they can easily choose between risky and safe investment opportunities therefore creditors will be afraid to provide them loan because such firms might choose risky projects, thus they will charge high interest rate while giving loan to growing firms. So due to higher cost of debt growing firms will go for equity and will use less amount of debt. We use annual percentage increase in total assets to measure the growth variable. 


\section{Tangibility of Assets (TG)}

The proxy fixed assets divided by total assets is used to measure the tangibility variable. According to the theory of agency cost companies can use higher debt level to prevent managers attitude to consume excessive perks, because the problem of bankruptcy arises with increasing debt level so in case of bankruptcy managers will lose their incentives and job security, therefore they will utilize the funds in proper way. By using higher debt ratio companies can monitor the activities of managers when they have fewer tangible assets even at high cost of debt Grossman and Hart (1982). The positive association of tangibility of assets with dependent variable is the prediction of the theory of agency cost. POT suggest that companies will face the problem of asymmetric information when they have less amount of fixed assets, therefore such firms with less fixed assets will use more short term debt.

Trade-off theory predicts positive relation of tangibility with debt ratio. Tangible assets are collateralizable because they are acceptable to creditors as a security for issuing the debt. Therefore firms that has higher amount of fixed assets has the ability to avoid bankruptcy, because in the situation of default the company's assets must be seized, however the company will overcome the problem of bankruptcy. In today's changing world where there is asymmetric information, firms with higher fixed assets can easily obtain debt because it is acceptable to creditors. The interest rate for those firms who have more fixed assets will be lower because they can use this large amount of fixed assets as a security to creditors. On the other hand companies will find it difficult to obtain debt because of high cost of debt when they has small amount of fixed assets. Furthermore, by issuing secured debt companies can minimize the problem of asset substitution.

\section{Profitability (PR)}

We take net income before taxes and divide it by firm's total assets to measure profitability. Trade-off theory of capital structure states that high profitable firms will use more debt due to tax benefits of debt. The reason is that high profitable firms have an increased ability to meet debt repayment obligations, and that's why they are less likely subject to bankruptcy risk. Thus to maximize their tax shield they will demand more debt at more attractive cost. The agency costs of free cash flow are minimized by higher debt ratio because the interest burden reduces the amount of funds available to managers. According to Ross (1977), when companies issue debt it gives positive indication to the market that the firm is performing well and managers have confidence about the company future returns. He further states that firms will face the problem of bankruptcy when they use over exceeded debt. Thus this reason shows that profitability has positive association with dependent variable debt ratio.

According to POT profitable firms will give first priority to their internal funds as compare to external funds Myer and Majluf (1984); and firms who have a large amount of retained earnings (profitability) will first finance their investments with retained earnings. The reason behind using small amount of debt in their capital structure by profitable firms is that they can obtain sufficient funds through retained earnings. It is the cheapest source of finance and has no adverse selection problem as compare to debt and equity. However, firms prefer debt against equity when external funds are necessary due to its lower information costs.

We also used qualitative variable (dummy) in our study, where 0 is given to financial sector and 1 to non-financial companies. 


\section{RESEARCH HYPOTHESIS}

Pecking Order Theory

\section{Hypothesis 1}

H1a: The association of dependent variable with tangibility is negative

H1b: There is direct positive association of growth opportunities with dependent variable.

H1c: The association of profitability with dependent variable is inverse.

H1d: The association of liquidity with dependent variable is negative.

\section{Trade-Off Theory}

\section{Hypothesis 2}

$\mathrm{H} 2 \mathrm{a}$ : The association of tangibility with dependent variable is positive.

$\mathrm{H} 2 \mathrm{~b}$ : The association of size with dependent variable is positive.

$\mathrm{H} 2 \mathrm{c}$ : The association of NDTS with dependent variable is negative.

\section{Theory of agency cost}

\section{Hypothesis 3}

H3a: The association of size and dependent variable is positive.

In table 1 we have shown different factors that affect capital structure, the proxies we used for these factors, and some previous studies that have used these proxies.

\section{ANALYSIS AND INTERPRETATION OF RESULTS}

\section{Statistical Analysis}

\section{Descriptive Statistics}

In table 1 we have shown descriptive statistics for six explanatory variables and dependent variable debt ratio. These include the median, mean, standard deviation, min and max values for the duration of 14 years from 2000 to 2013. 
TABLE 1

Fourteen-year summary of Descriptive statistics

\begin{tabular}{llllllll}
\hline & DR & PR & TG & GR & NDTS & LQ & SZ \\
\hline Whole sample & & & & & & & \\
Min & 0.0294 & -0.7256 & 0.0016 & -0.4825 & 0.0012 & 0.3845 & 4.2531 \\
Max & 1.1752 & 0.6624 & 1.0010 & 12.625 & 0.3124 & 4.6452 & 12.625 \\
Mean & 0.7154 & 0.0586 & 0.1024 & 0.2845 & 0.0312 & 1.0462 & 7.6547 \\
Median & 0.7024 & 0.0285 & 0.0512 & 0.2321 & 0.0100 & 1.0245 & 8.8654 \\
Std. Dev & 0.1852 & 0.1044 & 0.2312 & 0.7852 & 0.0512 & 0.2451 & 3.6547 \\
& & & & & & & \\
Financial sector & & & & & & & \\
Min & 0.4924 & -0.1124 & 0.0039 & -0.2102 & 0.0009 & 0.5012 & 5.24873 \\
Max & 1.1324 & 0.2914 & 0.4921 & 9.6210 & 0.0824 & 2.5201 & 14.4200 \\
Mean & 0.7925 & 0.0492 & 0.0574 & 0.3324 & 0.0102 & 1.3924 & 10.1924 \\
Median & 0.8124 & 0.0192 & 0.0312 & 0.2014 & 0.0069 & 1.0492 & 12.1824 \\
Std. Dev & 0.1142 & 0.0512 & 0.1121 & 1.0594 & 0.0102 & 0.2314 & 1.38421 \\
& & & & & & & \\
Non-financial sector & & & & & & \\
Min & 0.0412 & -0.8102 & 0.0015 & -0.4954 & 0.0011 & 0.3824 & 4.4251 \\
Max & 0.7724 & 0.6824 & 1.00012 & 2.4625 & 0.2345 & 3.6245 & 11.321 \\
Mean & 0.4924 & 0.0885 & 0.1942 & 0.1821 & 0.0510 & 1.1825 & 5.6584 \\
Median & 0.5147 & 0.0692 & 0.0845 & 0.2631 & 0.0182 & 1.0324 & 7.6245 \\
Std. Dev & 0.2145 & 0.1624 & 0.3125 & 0.3654 & 0.0584 & 0.3245 & 1.4821 \\
\hline
\end{tabular}

\section{Correlation Matrix}

We have found several observations that are noteworthy when we studied the correlations between independent variables. First, it is clear that size and growth have direct positive association, which means that firms that are large in size have higher growth rate and they grow more as compare to small firms and second it can be seen that large firms do not have higher amount of fixed assets. The reason that large firms grow more is that higher amount of funds are required for research and development which large firms can afford, thus due to this reason the growth opportunities of large firms will increase because of their ability to add new product lines.

TABLE 2

Correlation Matrix

\begin{tabular}{lllllll}
\hline Variables & SZ & LQ & NDTS & GR & TG & PR \\
\hline SZ & 1 & & & & & \\
LQ & 0.003 & 1 & & & & \\
NDTS & -0.142 & -0.052 & 1 & & & \\
GR & 0.024 & -0.524 & -0.025 & 1 & & \\
TG & -0.005 & -0.654 & -0.042 & -0.045 & 1 & 1 \\
PR & -0.156 & -0.425 & 0.005 & -0.654 & 0.025 & 1 \\
\hline
\end{tabular}




\section{REGRESSION ANALYSIS}

Regression Analysis Result-1

We have used Panel least square regression to find the impact of independent variables on debt ratio which is the dependent variable of the study using data for the entire sample. In table 3 it can be seen that variables profitability and liquidity have an inverse correlation with debt ratio whereas the association of tangibility \& growth with dependent variable is positive, however non-debt tax shield and debt ratio has insignificant negative relationship.

TABLE 3

Result of Regression Output (Entire Sample)

\begin{tabular}{lllll}
\hline Variables & Coefficient & Std. Error & t-Statistic & Prob. \\
\hline SZ & 0.052473 & 0.003142 & $6.45217^{*}$ & 0 \\
LQ & -0.045712 & 0.019547 & $-2.19245^{* *}$ & 0.0334 \\
NDTS & -0.008542 & 0.013254 & -0.96524 & 0.3965 \\
GR & 0.754213 & 0.215245 & $3.56247^{*}$ & 0 \\
TG & 0.067847 & 0.048641 & $1.83125^{* * *}$ & 0.0866 \\
PR & -0.295414 & 0.076421 & $-4.42145^{*}$ & 0 \\
Intercept & 0.152356 & 0.039652 & $4.54217^{*}$ & 0 \\
\hline
\end{tabular}

*significant at $1 \%$ level, **significant at $5 \%$ level, ***significant at $10 \%$ level

\section{Regression Analysis Result-2}

Maximum likelihood and Tobit model for the estimation of regression was used by Rajan and Zingales (1995) and they argue that the results obtained using OLS and some alternative techniques are very much similar. Their findings are also confirmed by Bevan and Danbolt (2002). In this study total $67 \%$ variation in the dependent variable as shown in table 6 is related to the values of all six explanatory variables of the study as evidenced in R-square value. However, the rest of the variation is due to factors other than determinants studied in this study. F-statistic shows the validity of the model. In our case F- statistic shows that overall models are significant, because regression is generally considered significant with F-statistics have significance values of 5 percent or less. 
TABLE 4

The Result of Dummy Variable Regression

\begin{tabular}{lllll}
\hline Variables & Coefficient & Std. Error & t-Statistic & Prob. \\
\hline Intercept & 0.485211 & 0.029547 & $11.52471^{*}$ & 0.0000 \\
Size & 0.041254 & 0.002547 & $5.141453^{*}$ & 0.0000 \\
Liquidity & -0.059684 & 0.021021 & $-3.624153^{*}$ & 0.000 \\
Non-debt tax shield & 0.001958 & 0.007152 & 0.412548 & 0.6542 \\
Growth & 1.814257 & 0.402145 & $4.541243^{*}$ & 0.0000 \\
Tangibility & -0.312457 & 0.069854 & $-3.954725^{*}$ & 0.0000 \\
Profitability & -0.215477 & 0.066547 & $-2.65241^{*}$ & 0.0136 \\
DUM & 0.215427 & 0.056245 & $2.46321^{*}$ & 0.009 \\
Size*DUM & 0.018654 & 0.006823 & $4.63214^{*}$ & 0.000 \\
Liquidity*DUM & -0.102654 & 0.041245 & $-3.35421^{*}$ & 0.000 \\
Non-debt tax shield*DUM & -0.035214 & 0.028652 & -0.35214 & 0.218 \\
Growth*DUM & -1.546524 & 0.423145 & $-4.22451^{*}$ & 0.000 \\
Tangibility*DUM & 0.284657 & 0.079654 & $3.88965^{*}$ & 0.000 \\
Profitability*DUM & -0.243514 & 0.071324 & $-3.63251^{*}$ & 0.002 \\
R-squared & 0.582414 & Mean dependent var & 0.690390 \\
Adjusted R-squared & 0.576845 & S.D. dependent var & 0.215861 \\
S.E. of regression & 0.124810 & Akaike info criterion & -1.281542 \\
Sum squared resid & 4.797886 & Schwarz criterion & & -1.117432 \\
Log likelihood & 220.3283 & F-statistic & & 50.16780 \\
Durbin-Watson stat & 0.631780 & Prob (F-statistic) & & 0.000000 \\
\hline
\end{tabular}

*significant at $1 \%$ level, $* *$ significant at $5 \%$ level, ***significant at $10 \%$ level

Dum represents a dummy variable, a value of 0 is given to firm that belongs to financial sector and a value of 1 is given to firm in the non-financial sector.

\section{Discussion of Results}

In this part of the study we are going to interpret the observed relations between dependent and independent variables. In table 5 and 6 we have shown the expected and observed relationships between dependent variable and six explanatory variables for the firms in the financial and non-financial sector.

TABLE 5

Expected and observed theoretical signs with Explanatory variables-Financial sector

\begin{tabular}{lcccc}
\hline Proxy & TOT & POT & ACT & Sign Observed \\
\hline Tangibility & + & - & + & - \\
Size & + & - & + & + \\
Growth & - & + & - & + \\
Profitability & + & - & $?$ & - \\
NDTS & - & $?$ & $?$ & + \\
Liquidity & + & - & $?$ & -
\end{tabular}

Where TOT, POT and ACT stands for pecking order, trade off and agency cost theory respectively 
TABLE 6

Expected and observed theoretical signs with independent variables-non financial sector

\begin{tabular}{lcccc}
\hline Proxy & TOT & POT & ACT & Sign Observed \\
\hline Tangibility & + & - & + & + \\
Size & + & - & + & + \\
Growth & - & + & - & + \\
Profitability & + & - & $?$ & - \\
NDTS & - & $?$ & $?$ & - \\
Liquidity & + & - & $?$ & - \\
\hline
\end{tabular}

The explanatory variable size has direct positive association with debt ratio and is statistically significant in the financial as well as the non-financial sector. This result is supported by trade-off theory that fixed direct costs of bankruptcy consist of a smaller portion of the total value of larger companies, therefore larger firms will be more willing to take more debt, because of low chances of bankruptcy. Larger firms can easily raise debt for financing, because this cost is smaller for them. Moreover we can say that larger firms included in our sample can easily raise funds, because majority of them are government controlled (partial or complete) due to which their chances of bankruptcy are low. Fauzi et al, (2013), Booth et al; (2001), Shah and Hijazi (2004), Sayeed (2007), Fitim Deari and Media Deari (2009), Sabir and Malik (2012), Çekrezi, (2013) and Naveed et al, (2010), are some of the studies that found the same association.

We use current ratio to measure liquidity of the firms; it can be calculated by taking current assets of company and dividing by the current liabilities. This ratio shows company's ability to pay their short term obligations. Pecking order theory as we said earlier predicts that firms will be less dependent on debt, when they have higher internal funds. Firms in the financial and non-financial sectors maintain high liquidity therefore they can generate high cash inflows. Hence, such firms are less dependent on debt as compare to low liquidity firms in the two sectors as predicted by pecking order theory. This result is similar to the findings of Eriotis, Vasilou and Neokosmidi (2007), Suhaila et al (2008), Naveed et al, (2010), Afza and Hussain (2011) and Pathak (2010) on 139 Indian firms.

In this study we found that the association of variable NDTS with the dependent variable is insignificant in both sectors. Therefore we can say that our result goes against the predictions of trade-off theory of capital structure which predicts negative association. One reason for this statistically insignificant association of NDTS with dependent variable debt ratio is that in Pakistan, tax rate does not fluctuate with the income level; there is a constant rate of tax in Pakistan. According to Shah and Khan (2007) there are three straight rates in Pakistan: the first one is applicable to commercial organizations in government ownership, second is applicable to public limited companies, And third to organizations in financial sector. Therefore companies do not used non-debt tax shield (depreciation) as a substitute to debt ratio to stop net income from going into a next high tax bracket. Our result insignificant association is in favor with the results found by Shah and Khan (2007), Sayeed (2007), Ilyas (2008) and Fitim Deari and Media Deari (2009). However on the other hand the result found by Ozkan (2001); and Zurigat (2009), Afza and Hussain (2011) are negative and significant. 
Firms in the two sectors achieved a high growth rate in the period 2000-2013. Therefore we can say that companies that are growing will use more debt. The growth variable is an important determinant for deciding the capital structure decisions in the two sectors of Pakistan and has a direct positive association with dependent variable debt ratio. Shah and Hijazi (2004), Cai et al. (2008), Kôrner (2007), Fauzi et al, (2013), Forte, Barros and Nakamura (2013), Akinyomi and Olagunju (2013) and Pathak (2010) also explored similar results.

Tangibility, with positive coefficient is significantly related to debt in overall findings. The result also shows that it is significantly positively correlated with dependent variable in the non-financial sector of Pakistan. Thus this indicates that the variable tangibility in the non-financial sector of Pakistan is an important determinant of the capital structure. Our result positive association is similar to the prediction of trade-off theory of Jenson and Meckling (1976) and Myer's (1977). The reason for the positive association in the non-financial sector of Pakistan is quite obvious. The benefit of using debt financing to creditors is that they receive uninterruptible stream of income due to debt investment except in case of bankruptcy. Jean-Laurent Viviani (2004), Shah and Khan (2007), Ilyas (2008), Fauzi et al, (2013), Sabir and Malik (2012) Akinyomi and Olagunju (2013), and Pathak (2010) also found that tangibility variable has positive association with dependent variable. Our result negative association of tangibility variable with dependent variable debt ratio in financial sector supports the prediction of Pecking order theory. In a study done on a sample of Macedonian listed and unlisted firms Fitim Deari and Media Deari (2009), forward a questionnaire to the managers of sample firms, most of them reply that they give higher priority to growth and profitability of companies as compare to fixed assets for providing debt. Sayeed (2007) in energy sector of Pakistan also find negative relation between tangibility of assets and financial leverage.

At the overall level and in sector wise analysis the data from the sample indicates that an increase in the debt ratio leads to lower profitability. The result shows that the association between the profitability variable and dependent variable debt ratio is negative, and there is enough evidence in support of this association. To justify this negative association we would say that in Pakistan high profitable firms in the two sectors first prefer their internal funds against external funds, and they retain some of their earnings to be used for financing their projects in the near future. Retained earnings according to Frydenberg (2001) is an important and cheapest source for financing companies operations, therefore the dependence of highly profitable firms on external funds will be low. Our result negative relationship supports the prediction of POT. The result also supports the findings of Frank and Goyal (2004), Forte, Barros and Nakamura (2013), Cekrezi, (2013) and Sabir and Malik (2012).

\section{TESTING HYPOTHESIS}

\section{Pecking Order Theory}

\section{Hypothesis 1a}

In the financial sector we will reject the null hypothesis at the $1 \%$ level; however it will not be rejected at the 1 percent level for non-financial companies.

\section{Hypothesis $1 \mathrm{~b}$}

We found positive association of growth with dependent variable debt ratio, and this relation is significant at the $1 \%$ level in the financial as well as non-financial sector. Thus we will reject the null hypothesis in favors of Hi. 


\section{Hypothesis 1c}

We found that profitability variable is significantly negatively correlated with debt ratio in the financial and non-financial sector at the 5\% and $1 \%$ level respectively. So $\mathrm{H} 0$ is rejected in favor of $\mathrm{H} 1$.

\section{Hypothesis 1d}

Our result supports prediction of pecking order theory. Liquidity is negatively associated with debt ratio in the financial and non-financial sector at the $1 \%$ level. Thus we reject Ho in favors of $\mathrm{H} 1$ in the two sectors.

\section{TRADE-OFF THEORY}

\section{Hypothesis 2a}

We found that the association between tangibility and debt ratio is negative in the financial sector. Therefore we cannot reject Ho. But in the non-financial sector tangibility and debt ratio has positive relationship, which means to reject Ho.

\section{Hypothesis 2b}

We found positive link between size and debt ratio in both sectors. Thus H0 is rejected.

\section{Hypothesis 2c}

The association of NDTS with dependent variable is insignificant in both sectors; therefore we would not reject the null hypothesis.

\section{Agency Cost Theory}

\section{Hypothesis 3a}

According to the theory of agency cost size and debt ratio has positive relationship. We also found significant positive association between size and dependent variable debt ratio. Thus we will reject null hypothesis in favors of alternative hypothesis.

\section{CONCLUSION}

This paper examines the role and importance of different firm characteristics that explain financial structure as well as the theories that best fit in Pakistani context. The sample of the study consists of firms extracted from financial (70 firms) and non-financial (120 firms) sectors listed on the KSE for a period of 2000-2013. Secondary data is extracted from firm's annual reports. The sources like SBP publications; Bloomberg businessweek and KSE were used to collect data. The results indicate that firms in the two sectors prefer funds generated internally for financing their assets. Moreover debt will be preferred to equity once external funds are required. The pecking order appears to be a good description of financing behavior for a large sample of firms over a long time period after accounting for debt capacity. We have also studied agency theory of the firm however there was little evidence to support the Agency cost theory. 


\section{STUDY LIMITATIONS}

The research conducted in this study has the following limitations:

- The study will focus on firms listed on the KSE only and therefore does not represent unlisted companies.

- To disclose the choices of capital structure, we would say that the determinants we used in this study are also used in many research studies done before and are most accredited. Four attributes we selected primarily were identified by Rajan and Zingales (1995); however we did not find enough financial data to use some other variables identified in previous studies and pick only two additional attributes.

\section{FUTURE RECOMMENDATIONS}

We recommend the following suggestions for future research:

- The authors must plan to study several macro-economic factors that influence capital structure decisions. This will include factors such as Capital Formation, Stock Market Development, Financial Stability of Country, Corporate Tax, Foreign Direct investment, etc.

- The researcher must add some other variables like the age of firm and their ownership structure and the difference between short and long term debt should be made.

\section{IMPLICATIONS OF RESEARCH}

After analyzing the findings and conclusions of the study we draw the following implications:

- For the availability of long term debt in Pakistan the bond market needs improvement, so that firms will have more choices to raise funds for financing their projects. Thus a country that is not developed yet needs to improve their bond market because it is important for its financial development. Furthermore, the inefficiencies of credit management and practices should be taken into consideration because such inefficiencies hinder the objectives of monetary policy.

- As Pakistan is a developing market, therefore this study demonstrates that existing theoretical literature concerning capital structure can be applied to Pakistani market. Many factors that were found significant in countries that were not developed like Pakistan are the same as we found in our study. 


\section{REFERENCES}

Abdeljawad, I. Nor, M.F., Ibrahim, I. and Rahim, A.R. (2013). "Dynamic Capital Structure Trade-off Theory: Evidence from Malaysia", Proceedings of $3^{\text {rd }}$ Global Accounting, Finance and Economics Conference 5-7.

Abubakar Sayeed (2007). "The Determinants of Capital Structure in Energy Sector”, A study of listed firms, SE-371 79, Karlskrona Sweden.

Afza, T. Hussain, A. (2011). "Determinants of Capital Structure across Selected Manufacturing Sectors of Pakistan”, International Journal of Humanities and Social Science, Vol. 1 No. 12.

Akinyomi, J.O., and Olagunju, A. (2013). "Determinants of Capital Structure in Nigeria", International Journal of Innovation and Applied Studies, Vol. 3 No. 4, pp. 999-1005.

Aremu, Ayanda, M. Christopher, I. Mudashiru, A. Isaac, I. (2013). "Determinants of Capital Structure in Nigerian Banking Sector", International Journal of Academic Research in Economics and Management Sciences, Vol. 2, No.4.

Awan, N.T., Rashid, R., Rehman, Z.R. (2011). "Analysis of the determinants of Capital Structure in sugar and allied industry", International Journal of Business and Social Science, Vol. 2 No. 1.

Bradley, M., Jarrel, G.A, and Kim, E.H. (1984). "On the existence of an optimal capital structure: Theory and evidence", Journal of Finance, 39, 857-878. "How Firm Characteristics Affect Capital Structure: An Empirical Analysis".

Bevan, A. and Danbolt, J. (2002). "Capital structure and its determinants in the UK-a decompositional analysis", Applied Financial Economics 12, 159-170.

Booth, L., V. Aivazian, A. Demirguc-Kunt, and V. Maksmivoc (2001). "Capital structures in developing countries", Journal of Finance Vol. 56, 87-130.

Bulent, K. and Cuneyt, O. and Arif, O. (2013). "Determinants of Capital Structure: Evidence from a Major Emerging Market Economy”. Online at http://mpra.ub.uni-muenchen.de/48415/.

CAI K., R. Fairchild, and Y. Guney (2008). "Debt maturity structure of Chinese companies", Pacific-Basin Finance Journal 16, 268-297.

Çekrezi, A. (2013). "Impact of Firm Specific Factors on Capital Structure Study of Albanian Firms", European Journal of Sustainable Development, Vol. 2, No. 4, pp. 135-148.

DeAngelo, H., Masulis, R.W. (1980). "Optimal capital structure under corporate and personal taxation”, Journal of Financial Economics, 8, 3-30.

Deari, F. Deari, M. (2009). "The determinants of capital structure: Evidence from Macedonian listed and unlisted companies", Journal of Finance.

Delcoure, N. (2007). "The determinants of capital structure in transitional economies", Journal of International Review of Economics and Finance, 16, 400-415. 
Eriotis, N., Vasilou, D. and Neokosmidi, Z.V. (2007). "How firm characteristics affect capital structure: an empirical study", Managerial Finance, 33, 5, pp. 321-331.

Fama, F. \& French, R. (2005). "Finance Decisions: Who issue stock"? Journal of financial Economics, 76, 549-582.

Fama, E.F., and Miller M.H. (1972). “The Theory of Finance”. Holt, Rinehart, and Winston: New York.

Fauzi, F. Yani, A. Jl. Basyith, A. (2013). “The Determinants of Capital Structure: An Empirical Study of New Zealand-Listed Firms", Asian Journal of Finance \& Accounting, Vol. 5, No. 2 .

Forte, D. Barros, A.L., Nakamura, T.W. (2013). "Determinants of the Capital Structure of Small and Medium Sized Brazilian Enterprises", BAR, Rio de Janeiro, Vol. 10, No. 3, pp. 347-369.

Frank, M.Z. and Goyal, V.K. (2004). "Capital structure decision: Which Factors are really important? Draft".

Grossman, S. \& Hart, O. (1982). "Corporate Financial Structure and Managerial Incentives". The Economics of information and Uncertainty, Edited by J. McCall. Chicago: University of Chicago press, 107-137.

Ilyas, J. (2008). "The Determinants of Capital Structure: Analysis of Non Financial Firms Listed in Karachi Stock Exchange in Pakistan". The Journal of Finance, 45, pp. 321-49.

Jahanzeb, A. Rehman, S. Bajuri, H.N. Karami, M. Imousaabad, A.A. (2014). "Trade-Off Theory, Pecking Order Theory and Market Timing Theory: A Comprehensive Review of Capital Structure Theories", Research Publish Journals pp: (11-18), Available at: www.researchpublish.com.

Jensen, M.C. \& Meckling, W.H. (1976). "Theory of the firm: managerial behavior, agency costs and capital structure", Journal of Financial Economics, 3: 306-65.

Jensen, M (1986). "Agency Cost Free Cash Flow, Corporate Finance, and Takeovers", American Economic Review, 76(2), 323-329.

Joseph P. H. Fan, Titman S., and Twite, G. (2012). "An International Comparison of Capital Structure and Debt Maturity Choices", Journal of Financial and Quantitative Analysis, Vol. 47, No. 1, Pp. 23-56.

Kayo, K.E., Kimura, H. (2011). "Hierarchical determinants of capital structure", Journal of Banking \& Finance, 35 358-371.

Kila, M.S., and Mahmood, W. Mansor, W. (2008). "Capital Structure and Firm Characteristics: Some Evidence from Malaysian Companies". The Journal of Finance, 45, pp. 321-49.

Modigliani, F. \& Miller, M.H. (1963). "Corporate income taxes and the cost of capital: a correction”, American Economic Review, 53, June, pp. 443-53. 
Modigliani, F. \& Miller, M.H. (1958). "The cost of capital, corporate finance and the theory of investment", American Economic Review, 48, pp. 261-97.

Myers, S.C. (1984). “The capital structure puzzle”, Journal of Finance, 39 (3): pp. 575- 92.

Myers, S.C. (2001). “Capital Structure”, Journal of Economic Perspectives, 15(2), 81-102.

N. Ahmad, Z. Ahmad \& I. Ahmad. (2010). "Determinants of Capital Structure: A Case of Life Non-financial Sector of Pakistan”, European Journal of Economics, Finance and Administrative Sciences, ISSN 1450-2275 Issue 24.

Opler, T.C., Saron, M.\& Titman, S. (1997). "Designing Capital Structure to create shareholder value", Journal of Applied Corporate Finance, 10(1), 21-32.

Ozkan, A. (2001). "Determinants of Capital Structure and Adjustment to Long Run Target: Evidence from UK Company Panel Data", Journal of Business Finance and Accounting, 28(1/2), 175-198.

Qayyum, S. (2013). "Determinants of capital structure: An empirical study of Cement industry of Pakistan", Interdisciplinary Journal of Contemporary Research in Business, Vol 4, No 11.

Rajan, R.G and Zingales, L. (1995). "What do we know about capital structure? Some evidence from international data", Journal of Finance, 50, pp.1421-60.

Ross, S. (1977). "The determination of financial structure: The incentive signaling approach", Bell Journal of Economics, 8, 23-40.

Sabir, S. and Malik, A.Q. (2012). "Determinants of Capital Structure - A Study of Oil and Gas Sector of Pakistan", Interdisciplinary Journal of Contemporary Research in Business, Vol 3, No 10 .

Shah \& Khan (2007). "Determinants of Capital Structure: Evidence from Pakistani Panel Data”, International Review of Business Research Papers, Vol. 3 No.4 October 2007 Pp.265-282.

Shah \& Hijazi (2004). "The Determinants of Capital Structure of Stock Exchange-listed Non-financial Firms in Pakistan", The Pakistan Development Review, 43: 4 Part II (Winter 2004) pp. 605-61.

Tamulyte, J. (2012). "The determinants of capital structure in the Baltic States and Russia", PEI Electronic Publications, www.tse.fi/pei.

Titman, S and Wessels, R. (1988). "The determinants of capital structure choice", The Journal of Finance, 43, 1, pp. 1-19.

Um, T. (2001). "Determination of Capital Structure and Prediction of Bankruptcy in Korea", unpublished $\mathrm{PhD}$ thesis Cornell University. 
Wahab, A.R., Amin, M.S.M., and Yusop, K. (2012). "Determinants of Capital Structure of Malaysian Property Developers", Middle-East Journal of Scientific Research, 11 (8): 1013-1021.

Zikmund, W.G. (2003). "Business Research Methods $7^{\text {th }}$ ed", Thomson Learning: Mason. Ohio, USA.

Zurigat, Z. (2009). "Pecking Order Theory, Trade-Off Theory and Determinants of Capital Structure: Empirical Evidence from Jordan”. Journal of Financial Research, 22: 161-187 